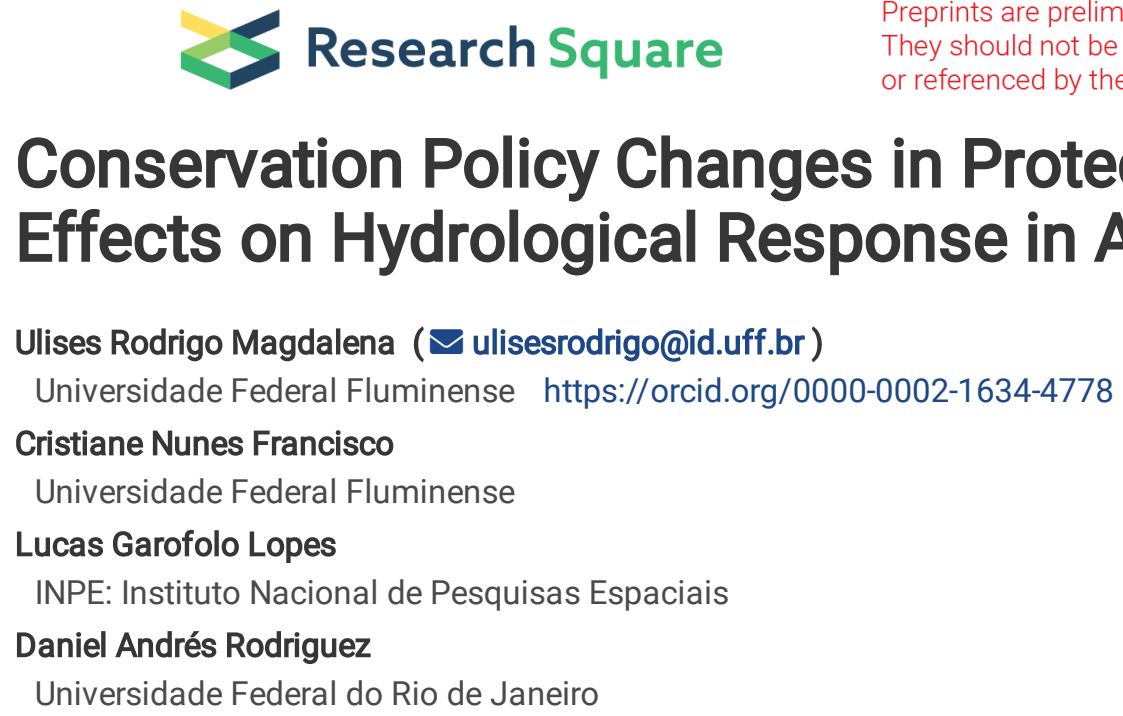

\title{
Conservation Policy Changes in Protected Areas on Hilltops: Effects on Hydrological Response in A Small Watershed.
}

\section{Research Article}

Keywords: Environmental function, Water resources, Environmental legislation, Protected area.

Posted Date: November 11th, 2021

DOI: https://doi.org/10.21203/rs.3.rs-762476/v1

License: @ (i) This work is licensed under a Creative Commons Attribution 4.0 International License. Read Full License 


\section{Abstract}

Public policies affecting land use/land cover also have an impact on water resource availability, and hilltop protected areas are a relevant factor in ensuring continued availability of water resources. The legislation ruling the delimitation of protected areas on hilltops has changed at the national level in 2012 and in Rio de Janeiro state in 2014. However, these environmental legislation changes did not take into account the feedback effects of restricting protected areas to hilltops on the regularity of hydrological responses in watersheds. As such, this manuscript sought to analyze the contribution of hilltop-only protected areas to continued water availability. We analyzed hydrological responses in the São João river watershed, which provides water for domestic, industrial, and agricultural uses in the Região dos Lagos municipalities of Rio de Janeiro state. Our results show that designating only hilltops as protected areas, as prescribed under the new pieces of legislation, does not prevent abrupt changes in hydrological responses that can lead to changes in streamflow volume and regularity as well as increases in sediment flows, which may compromise drainage systems and continued water supply due to reservoir silting. Therefore, we conclude that protecting hilltops only, as established under current Brazilian legislation, is not sufficient to safeguard the environmental function of maintaining water resource availability.

\section{Introduction}

Rainforests cover about 7\% of the Earth's surface, with estimates pointing to them being home to two-thirds of global biodiversity (DeFries et al., 2005; Estoque et al., 2019). As natural capital, rainforests are an important component of the water cycle, ensuring the continued availability of water for human activity.

Rainforests also perform functions that are strongly correlated with biodiversity, as evidenced by their direct influence on ecosystem services (e.g., water supply) and regulation (e.g., water availability and quality and the mitigation of extreme events). To some extent, ecosystem services and biodiversity can be considered synonyms (Andrade et al., 2020; Schröter et al., 2019). This strong overlap allows for more synergies in environmental protection strategy and public policy making, as the aims of both are to have landscapes whose functions or processes contribute, directly or indirectly, to human resources associated with fauna and flora variability (Costanza et al., 2017, 1997).

Biodiversity loss through land use/land cover (LULC) change, often driven by public policies structured by political-economic concerns, can result in water resource degradation scenarios (Rochedo et al., 2018). Several fields of science have investigated this association (Barral et al., 2019; Xiang et al., 2020), highlighting the direct and indirect effects of rainforest reduction on water availability and quality, water cycle changes and increased soil erosion in watersheds (Chen et al., 2007; Guo et al., 2019; Salemi et al., 2013; Spera et al., 2016; Sthiannopkao et al., 2007).

Brazil, $58 \%$ of whose territory is covered by forests with different vegetation types (FAO, 2016), has suffered an intense deforestation and land degradation process as a result of weakened protected area demarcation legislation (Rochedo et al., 2018; Soares-Filho and Rajão, 2018). The legislation that governs the definition of contour lines for protected areas, wherein protected areas are defined as a geographical space of recognized importance for nature conservation associated with ecosystem services (Mitchell et al., 2018), was changed in 2012 with the enacting of Federal Law no. 12,651 (Forest Code) (Brasil, 2012).

The Forest Code is estimated to govern about 2.81 million square kilometers of remaining native vegetation in rural properties, equivalent to a stock of $\sim 105 \mathrm{GtCO}_{2} \mathrm{e}$ (billion tons of $\mathrm{CO}_{2}$ equivalent) (Soares-filho et al., 2014). It also establishes guidelines for the delimitation of protected areas called Permanent Preservation Areas (PPAs).

The Forest Code, first introduced in 1934 to define forest exploitation activity, was later amended in 1965 to better highlight the importance of the conservation and proper use of forest resources by creating "Permanent Protection Areas" (PPAs), defined then as areas to be protected regardless of native forest coverage. PPAs fulfill the environmental functions of protecting water resources, promoting landscape and geological stability and biodiversity, facilitating the gene flow of fauna and flora and soil protection, and providing for the well-being of populations. (Brasil, 2012). In particular, hilltop PPAs are deemed to cover two-thirds of a hill's height as measured from its baseline. (Brasil, 2012). Between 1990 and 2001, the Forest Code was changed by a number of Presidential Orders that changed delimitation guidelines for PPAs (Oliveira and Filho, 2016; Soares-filho et al., 2014; Tambosi et al., 2015).

However, in 2012, the Forest Code received a major overhaul that redefined the boundaries of PPAs, whereby hilltop protected areas had their protected area coverage reduced by $87 \%$ in Brazil (Soares-filho et al., 2014). Such reduction may cause a direct impact on 
the hydrological responses of watersheds, given that $95 \%$ of the water that supplies drainage systems comes from hills in mountainous areas, with possible consequences for availability to the general population (Hallema et al., 2016; Shakya and Chander, 1998; Vieira et al., 2018).

Brazil's legal framework is based on the concept of the Kelsen Pyramid, where hierarchically higher standards institute and regulate the creation of methods used in hierarchically lower standards (Kelsen, 1967). As such, the Brazilian Constitution gives the states the right to enact their own environmental standards, provided those are in compliance with the standards established by the Federal Government (Brasil, 2016). In 2014, the Rio de Janeiro State Environmental Institute (Inea) published Resolution no. 93 ("Inea Resolution") to prevent gaps in the delimitation of PPAs on hilltops and to preserve the landscapes of the Rio de Janeiro state, in compliance with the criteria presented by the Forest Code (Frega, 2014).

As a result, changes to LU/LC frameworks created by different laws governing the delimitation of protected areas on hilltops can have direct effects on watershed services (Aghsaei et al., 2020; Li et al., 2018; Vieira et al., 2018). While measuring the magnitude of these impacts with high degrees of accuracy requires monitoring over time, it is possible to obtain estimates thereof through numerical modelling approaches that can simulate possible scenarios against LU/LC changes, allowing for the evaluation of their effects on ecosystem services performed by vegetation on hydrological processes. (Armenteras et al., 2019; Badham et al., 2019; Loucks et al., 2005). As such, we sought, in this manuscript, to assess the contributions of hilltop protected areas to hydrological responses and sediment control in the São João river watershed, located upstream of the Juturnaíba Reservoir in the state of Rio de Janeiro.

\section{Materials And Methods}

\subsection{Study area}

The São João river watershed (Fig. 1) is responsible for the water supply of the Região dos Lagos municipalities in Rio de Janeiro state. The study area is upstream of the Juturnaíba Lake, which became a reservoir in the 1970s. The watershed has an area coverage of $577 \mathrm{~km}^{2}$, and its main channel has been widened and straightened as a result of agricultural activity (Ikemoto and Napoleão, 2018). Moreover, it features a gauge station, called Correntezas Nova (catchment area cover of $400 \mathrm{~km}^{2}$ ), from which one can obtain streamflow data over long-term data time series.

The Juturnaíba reservoir (Fig. 1), apart from accumulating the largest water volume, is also used for flood control purposes in the São João river floodplain and to ensure water availability for farmland irrigation downstream of the river. The reservoir is used in two water supply systems. The first system serves the Araruama, Silva Jardim, and Saquarema municipalities, with a combined population of $\sim 340,000$ people, while the second system supplies coastal municipalities with large tourist inflows in summer Armação dos Búzios, Arraial do Cabo, Cabo Frio, São Pedro da Aldeia and Iguaba Grande - and a total population of 715,000 (including permanent residents and seasonal inflows) (Cunha, 1995; Ikemoto and Napoleão, 2018).

The watershed's relief is characterized by steep hillsides and an abrupt transition thereof to the floodplain, as well as the predominance of dissected and isolated gently sloping hills. Natural vegetation is the Atlantic Rainforest, a forest complex with high species richness and endemism rates. However, only 15\% of its original cover in the Brazilian territory remain, dispersed in fragments of which $80 \%$ are smaller than $0.5 \mathrm{~km}^{2}$ in area. Furthermore, only $9 \%$ of the remaining forest and $1 \%$ of the original forest areas are in protected areas (Ribeiro et al., 2009; Wagner et al., 2020).

The anthropic interventions carried out in the São João river modified the meandering channel patterns to rectilinear, reducing river size by $40 \%$ (Cunha, 1991). This, combined with the construction of the Juturnaíba reservoir, changed local morphology from meandering channels to decantation basins and removed the natural vegetation of the riparian zones. Moreover, the area saw increased erosion in tributary rivers, a gradual rise in peak streamflow, new flood zones (because of slower water velocity) and siltation of the main channel (Cunha, 1995, 1991).

\subsection{Acquisition of streamflow data on the São João river watershed}

Hydrological response estimates were obtained through the MHD-INPE hydrological model (Rodriguez and Tomasella, 2015) for the catchment area defined by the Correntezas Nova gauge station (Fig. 1). The LU/LC scenarios, developed by Magdalena et al. (2018), delimit the hilltop protected areas in question as established by the Forest Code and the Inea Resolution. To build the modeled scenarios, Magdalena et al. (2018) used the 2010 LU/LC maps for the state of Rio de Janeiro (Bastos and Napoleão, 2011). 
For this end, hilltop protected areas were characterized as comprising the upper two-thirds of hills with a minimum height of 100 meters and average slope greater than 25 degrees. Per the Forestry Code, hill baselines in wavy reliefs are defined as the lowest point between two hills. Meanwhile, for the Inea Resolution, hill baselines are defined by the nearby lowland or a nearby body of water. This difference in parameters for the definition of hill baselines results in an 1500\% difference in the total size of protected areas $(\sim 78.67$ $\mathrm{km}^{2}$ ) distributed and connected along the watershed when using Inea Resolution guidelines compared to the parameters defined in Forest Code, which leads to protected areas that are isolated and concentrated in water divisors totaling $\sim 5.53 \mathrm{~km}^{2}$ in area (Magdalena et al., 2018).

In total, we modeled seven scenarios using the definitions for hilltop protected areas from the Forest Code and the Inea Resolution (Table 1) (Fig. 2C, Fig. 2F, Fig. 2D and Fig. 2G), two of which were extreme scenarios and one a control scenario. We created the control scenario (Fig. 2A) based on the 2010 LU/LC maps for the state of Rio de Janeiro (Bastos and Napoleão, 2011), while, for the extreme case scenarios, one assumed the watershed is fully preserved (Fig. 2E) and the other assumed it has been fully deforested (Fig. 2B).

Table 1

LU/LC and protected vegetation scenarios according the protection parameters of the Forest Code and the Inea Resolution for the São João River watershed in Rio de Janeiro state.

\begin{tabular}{|c|c|c|c|}
\hline \multirow[t]{2}{*}{ Scenarios } & \multirow[t]{2}{*}{ Description } & \multicolumn{2}{|c|}{$\begin{array}{l}\text { Native vegetation } \\
\left(\mathrm{km}^{2}\right)\end{array}$} \\
\hline & & $\begin{array}{l}\text { Forest Code } \\
\text { (FC) }\end{array}$ & $\begin{array}{l}\text { Inea Resolution } \\
\text { (IR) }\end{array}$ \\
\hline Control & 2010 LU/LC Rio de Janeiro state map & 374 & \\
\hline 2 & Hilltop protected areas combined with LU/LC Rio de Janeiro state map & 375 & 378 \\
\hline 3 & $\begin{array}{l}\text { Hilltop protected areas combined with Rio de Janeiro state land cover used for } \\
\text { pasture. }\end{array}$ & 4 & 62 \\
\hline Pasture & Watershed fully deforested and converted to pasture. & 0 & \\
\hline Forest & Watershed fully preserved with Atlantic Rainforest. & 577 & \\
\hline
\end{tabular}

The MHD-INPE (Distributed Hydrological Model of the National Institute for Space Research) model is a regular grid-based model that uses a combination of the Xinanjiang model probabilistic approach (Zhao and Liu, 1995) and the principles used in the Topographybased hydrological model (TOPMODEL) (Beven and Kirkby, 1979) to simulate runoff generation. This model has been most wellknown in LU/LC change studies (Rodriguez and Tomasella, 2015) and for flood forecasting (Ovando et al., 2016; Tomasella et al., 2019).

The MHD-INPE uses hydrological response units in each grid cell, which results from a combination of soil type and land use. In this manuscript, soil classification was obtained from the Rio de Janeiro state soil map in Dantas, 2001, integrated into the calculations with use of the Height Above the Nearest Drainage algorithm (Rennó et al., 2008). The result allows for the classification of watershed into landscapes according to slope-channel connectivity, with the terrain normalized for water-soil interaction analysis (Nobre et al., 2011). It also contributes to the interflow of cells for purposes of calculating surface runoff production in the model.

Topographic information was obtained from the Digital Elevation Model (DEM), at 10-meter spatial resolution. In this case, the DEM was generated using the Top to Raster interpolator in ArcGIS ${ }^{\circledR}$ (Esri, 2019; Hutchinson, 1989; Hutchinson et al., 2011, 2009), at $1: 25,000$ ( 1 centimeter $=0.25$ kilometer) scale, relying on the contour lines provided by the Brazilian Institute of Geography and Statistics (IBGE).

The MHD-INPE parameterizes soils through their hydraulic properties (Tomasella and Hodnett, 2004). Vegetation parameters were obtained from specific literature (Niu et al., 2011; Xue et al., 1996). In particular, the parameters for Atlantic Rainforest vegetation were based on Ávila (2011), Freitas (2012), Marchiori et al. (2016) and Pinto et al. (2016). For the scenarios in which Atlantic Rainforest is 
converted to pasture, we applied a 30\% reduction in saturated hydraulic conductivity in the model simulations (Ksat); the rate was chosen based on the outcomes of Salemi et al. (2013).

As for the hydrometeorological and hydrological information required by the MHD-INPE, input data was obtained from databases maintained by the National Institute of Meteorology (INMET), National Institute for Space Research (INPE) and the National Water Agency (ANA).

\subsection{Model Calibration}

The MHD-INPE model was calibrated for the daily streamflow data set offered by the Correntezas Nova gauge station for the period from 1984 to 2003 (Fig. 1). Calibration was conducted via the automatic method described in Duan et al. (1992), with Nash-Sutcliffe (Nash) as the efficiency coefficient applied to streamflow (Nash) and logarithmic streamflow (logNash) calculations. When Nash shows values $\leq 0$, the model simulation does not result in better values than the mean observed streamflow numbers (Gupta et al., 2009). Simulations were validated using the method described in Moriasi et al. (2007), with Nash $>0.50$ considered acceptable.

\subsection{Framework of numerical experiments}

We developed numerical experiments applying different LU/LC scenarios (Table 2). In addition to the control experiment, which simulates the actual watershed status, we developed two extreme case experiments for comparison purposes.

Table 2

Overview of numerical experiments for LU/LC effects of hilltop protected areas considering the criteria in the Forest Code and Inea Resolution for analysis of hydrological responses in the São João river watershed

\begin{tabular}{|ll|}
\hline Experiments & Description \\
\hline Control & 2010 LU/LC maps of Rio de Janeiro state. Total native vegetation: $374 \mathrm{~km}^{2}$ \\
\hline 2CF & $\begin{array}{l}\text { Hilltop protected areas delimited per the Forest Code and assumed to consist of Atlantic Forest. For the rest of the } \\
\text { watershed, classification was per current LU/LC (control). This resulted in a 0.25\% increment in native vegetation. }\end{array}$ \\
\hline $3 \mathrm{CF}$ & $\begin{array}{l}\text { Hilltop protected areas delimited per the Inea Resolution and assumed to consist of Atlantic Forest. For the rest of } \\
\text { the watershed, classification was per current LU/LC (control). This resulted in a 1.46\% increment in native } \\
\text { vegetation. }\end{array}$ \\
\hline $3 \mathrm{RI}$ & $\begin{array}{l}\text { Hilltop protected areas delimited per the Forest Code and assumed to consist of Atlantic Forest. All other LU/LC } \\
\text { categories were converted to pasture. This resulted is native vegetation being preserved exclusively on hilltops, }\end{array}$ \\
\hline leading to an 89\% decrease in native vegetation
\end{tabular}

\subsection{Analysis of the modeled hydrological responses}

The MHD-INPE is a deterministic distributed hydrological model (Mohor et al., 2015) that subdivides the watershed into a regular grid of cells that can consist of one or more types of Hydrological Response Unit (HRU), understood here to be a homogeneous unit that yields the same response to the same input. The HRU is represented by parameters that determine water balance and the flow generation process resulting from the interaction between LU/LC and different soil types.

We estimated evapotranspiration from the Penman-Monteith equation (Allen et al., 1998). Water loss by canopy interception was estimated with the model proposed by Gash et al. (1995). Water transpiration captured by plant roots was estimated per the model in Jarvis (1989). Water routing between cells was calculated per the Muskingum-Cunge method (TUCCI and CLARKE, 1997).

The MHD-INPE takes three soil layers into consideration for estimates of evapotranspiration, soil water balance and water flows: (1) the surface layer, responsible for calculation of superficial runoff and immediate responses to atmospheric demands; (2) the intermediate layer, used for calculation of delay times for groundwater recharge according to rainfall and the maintenance of 
evapotranspiration during the dry season; and (3) the lower layer, responsible for sustained hydrological response by the watershed during the dry season, i.e. baseflow.

Saturated zone percentages were estimated using the TOPMODEL formulation (Beven and Kirkby, 1979). Water saturation in soil results in surface runoff generation (Dunne and Black, 1970), which can generate erosion, causing soil loss and displacement of sediment to the drainage system (Bruijnzeel, 2004; Chen et al., 2007; Guo et al., 2019).

For our analysis of the watershed's hydrological response patterns, we used indices to understand the Flow Duration Curve (FDC) (Ley et al., 2011). We selected four indices based on Ley et al. (2011). Three indices were calculated by dividing the FDC into three segments. The first includes the flows with exceedance probabilities of less than 0.02 , classified as the high-flow segment volume of the FDC. The second includes flows with exceedance probabilities between 0.2 and 0.7 , classified as the mid-segment slope of the FDC. And finally, the third segment includes flows with exceedance probabilities of over 0.7 , classified as the low-flow segment volume of the FDC. In addition to these, a seasonality index was also applied that described inter-annual average streamflow variations (Table 3 ).

Table 3

Indices used for performance analysis of the São João river watershed

\begin{tabular}{|c|c|c|c|}
\hline Index & Name & Calculation & Information \\
\hline Seasonality & Season & Season $=$ mreanWinter-meanSummer & Differences between winter and summer \\
\hline $\begin{array}{l}\text { high-flow segment } \\
\text { volume of the FDC }\end{array}$ & MWH & $\begin{array}{l}M W H=\mathbb{E}_{h=1}^{H} Q_{h} \\
\mathrm{~h}=1,2, \ldots H \text { flows with exceedance } \\
\text { probabilities }<0.02\end{array}$ & Watershed response to large precipitation events \\
\hline $\begin{array}{l}\text { low-flow segment } \\
\text { volume of the FDC }\end{array}$ & MWL & $\begin{array}{l}M W H=\mathbb{E}_{l=1}^{L} Q_{l} \\
\mathrm{I}=1,2, \ldots L \text { flows with exceedance } \\
\text { probabilities ranging from } 0.7 \text { to } 0.9\end{array}$ & $\begin{array}{l}\text { Long-term sustainability of flow ( } 0.9 \text { instead of } 1.0 \\
\text { because of interpolated missing data } 0.9 \text { to } 1.0 \text { ) }\end{array}$ \\
\hline $\begin{array}{l}\text { mid-segment slope } \\
\text { of the FDC }\end{array}$ & MS & $\begin{array}{l}\mathrm{MS}=\mathrm{m} 2-\mathrm{m} 7 \\
\mathrm{~m} 2, \mathrm{~m} 7: \text { flow exceedance } \\
\text { probability } 0.2 \text { and } 0.7\end{array}$ & $\begin{array}{l}\text { Vertical redistribution } \\
\text { of water }\end{array}$ \\
\hline
\end{tabular}

\subsection{Contribution of hilltop protected areas to soil erosion control in the São João river watershed}

To estimate the ecosystem services provided by hilltop protected areas specifically regarding soil erosion control in the watershed, we applied the Revised Universal Soil Loss Equation (RUSLE) (Benavidez et al., 2018; Wischmeier and Smith, 1958) (Table 4). The DEM used for RUSLE calculations had 10-meter spatial resolution. The rainfall data used to calculate the R factor was obtained from INMET and INPE. 
Revised Universal Soil Loss Equation. Units: $\mathrm{t}=$ tons; $\mathrm{ha}=$ hectare; $\mathrm{MJ}=$ megajoules; $\mathrm{mm}=\mathrm{millimeter} ; \mathrm{h}=\mathrm{hours}$

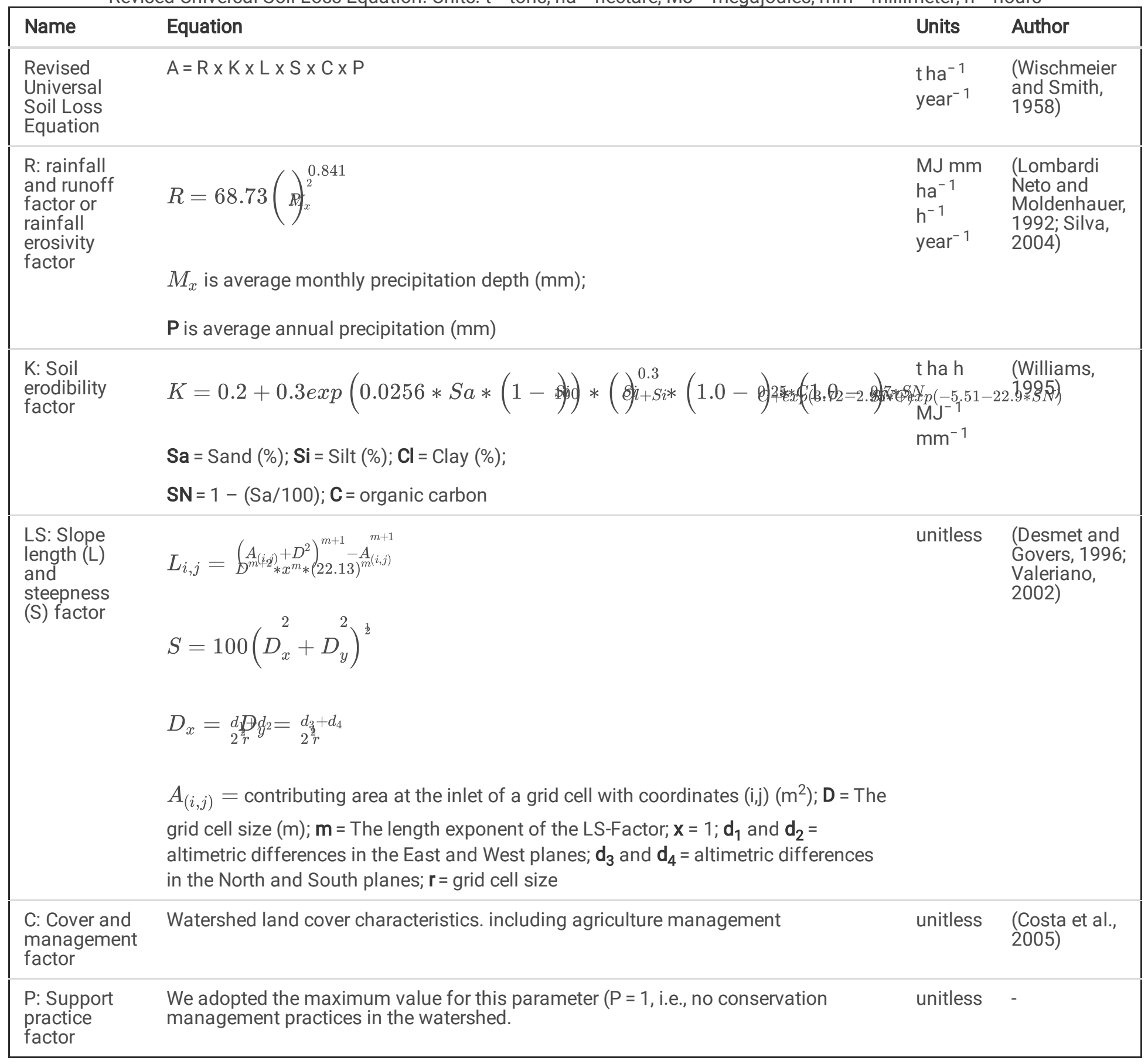

\section{Results And Discussion}

\subsection{Simulation and calibration}

Automatic calibration resulted in 0.60 for Nash and 0.59 for logNash, both considered satisfactory per the parameters in Moriasi et al. (2007). However, the results show that the MHD-INPE had difficulties in simulating the extreme streamflow peaks observed. This can be a result of the spatially uniform recharge rate adapted by TOPMODEL (Rodriguez and Tomasella, 2015) and the relief of the watershed itself, particularly its hillsides that abruptly end into the floodplain, a favorable scenario for quick streamflow responses in rainfall events. 
However, the watershed shows silting tendencies because of the straightening process and lack of maintenance along the main river course. This, combined with the watershed's relief, results in overflow over the river's banks, which changes the streamflow dynamics. Nevertheless, the hydrological model performed in a similar pattern to that of the observed data in the dry season (Fig. 3).

\subsection{Hydrological responses of the São João river watershed}

As expected by the water balance, in long-term average values, evaporation reduction (Fig. 4B) suggests an increase in streamflow generation (Fig. 4A). The hydrological responses simulated with the LU/LC scenarios wherein only the hilltop protected areas are preserved per the Forest Code (3CF) or the Inea Resolution (3Cl) show similar variation to the extreme scenario of the completely deforested watershed. In contrast, given that most areas defined as protected areas are currently forested, the hydrological response scenarios for Control, $2 \mathrm{CF}$ and $2 \mathrm{RI}$ are close to the response found when the watershed is fully forested. In these scenarios, despite the lower evapotranspiration at the dry season and the beginning of the rainy season, streamflow is still lower than in the Forest scenario because of the lower soil hydraulic conductivity capacity inputted in the model.

An analysis of long-term monthly mean amounts reveals a rise in the streamflow regime and a reduction in evapotranspiration processes in the seasonal variation, which shows the effects on maintaining forest cover only on the hilltop protected areas (Fig. 4A and Fig. 4B, 3CF and 3RI). In all other scenarios, among which the Forest scenario, mean hydro-climatic variables show behavior closer to that of the watershed's present state (Fig. 4A and Fig. 4B, Control).

The FDC descriptors, when applied to the numerical modelling results considering the Pasture and Forest scenarios, show two extreme hydrological response patterns (Fig. 5). Dry and rainy season streamflow rates are higher in the Pasture scenario (Fig. 5A and $5 \mathrm{C}$ ), with a greater slope in the middle section of the FDC (Fig, 5B), suggesting loss of regularity with rapid responses to rainfall events. Seasonal variation streamflow rates are also higher in the Pasture scenario (Fig. 5D).

The Control scenario shows a pattern close to that of the Forest scenario. The MWL index, associated with dry season streamflow rates, is close to that of the Forest scenario (Fig. 5A), while the MWH index, associated with the rainy season, is higher (Fig. 5C). The slope of the middle section of the FDC, shown by the MS index, is greater in the Control scenario than in the Forest scenario (Fig. 5B), revealing a quicker, less regular hydrological response; also, seasonal variation is greater in the Control scenario (Fig. 5D).

The addition of forest to current LU/LC in the hilltop protected areas shown in the 2CF and 2RI scenarios resulted in a decline in dry and rainy season streamflow rates (Fig. 5A and 5 C), along with changes in soil hydraulic properties and better hydrological response in the watershed (Fig. 5B and 5D). On the other hand, when the model assumes that only the hilltop protected areas have native forest (scenarios $3 \mathrm{CF}$ and $3 \mathrm{RI}$ ), the hydrological response of the watershed changes to a pattern similar to that of the Pasture scenario. In these scenarios, dry and rainy season volumes rise (Fig. 5A and 5C), while hydrological response is more rapid and less regulated (Fig. 5B and 5D).

Streamflow rate rises in the watershed under the native vegetation loss scenarios are associated with a direct response increase (Fig. 6A). As such, the São João river watershed shows direct response increases under scenarios 3CF and 3RI (Fig. 6A). Conversely, native vegetation loss is associated with a decline in response rates for baseflow, which is the phenomenon that feeds channel runoff at dry season (Fig. 6B).

This variation in flow paths is associated with variations in saturated zones, where direct runoff into the watershed occurs (Fig. 6C). The replacement of Atlantic Rainforest with pasture results in a decline in evapotranspiration (Fig. 4B), which, associated with a decline in soil water retention capacity, increases saturated zones. In the pasture scenarios (Pasture, 3CF, 3RI), the watershed keeps a higher saturated zone rate than in the Forest, Control, 2CF and 2RI scenarios.

Saturated zones had seasonal variation in size, covering a larger area of the watershed during the rainy season (January, February and March) than in the dry season (July, August and September) (Fig. 7). Under the Control scenario (Fig. 7A), saturated zones are clustered around the main channel where the floodplain is located.

In the Pasture scenario, saturated zones are the largest at both seasons, including regions with high elevation in the rainy season (Fig. 7B). On the other extreme, i.e., the Forest scenario, saturated zones are smaller and show fewer variations between seasons (Fig. 7E). The biggest differences between the Forest and Control scenarios (Fig. 7A) are in the size of the floodplain occupied by pastures (Fig. 2A). 
In a LU/LC scenario wherein the Atlantic Rainforest is restricted only to the hilltop protected areas (Fig. 7D and Fig. 7G), saturated zone size is close that of the Pasture scenario in the watershed (Fig. 7B).

In the scenarios that keep LU/LC as currently existing in most of the watershed (2CF, 2RI) (Fig. 7C and Fig. 7F), saturated zones are closer in size to those of the Forest scenario (Fig. 7B). This is because of the small area of hilltop classified as protected area under current legislation, which protects a smaller rate of natural vegetation than what is found in the current scenario (Magdalena et al, 2018). Nevertheless, we noted that the presence of forests on hilltops reduces saturated zones in the watershed (Fig. 7C, Fig. 7F, Fig. 7G).

These responses suggest that, although liquid discharges increase in volume, reducing native vegetation coverage to the minimum prescribed by law would affects water supply in the watershed, which can cause problems in water resource management in the Juturnaíba reservoir and intensify conflicts over water use. Besides, the greater streamflow rates in the rainy season suggest a rise in energy flows for sediment displacement, which may cause soil loss, silting of the main channel and deposit of sediments in the Juturnaíba reservoir (Chen et al., 2007; Cunha, 1995; Fohrer et al., 2001).

\subsection{Responses to sediment deposit controls in the São João River watershed}

Per our analysis of the spatial distribution of average annual soil loss in the watershed under the Control scenario, $76 \%$ of the catchment area shows values lower than $5 \mathrm{t} \mathrm{ha}^{-1}$ year $^{-1}$ (Fig. 8A). Nevertheless, $14 \%$ of the catchment area has an average loss of 5-30 t ha-1 year $^{-1}$ (slight and moderate). This soil loss is in lowland areas, a region currently covered with pasture areas because of the removal of floodplain vegetation and the riparian forest for the channeling of the São João river, as well as due to agricultural activity (Cunha, 1995, 1991). Areas showing severe and very severe soil loss amount to only $2 \%$ and $3 \%$ of the catchment area (Fig. 8A).

As expected, under the Pasture scenario, we see a decline in the share of areas with soil loss at less than $5 \mathrm{tha}^{-1}$ year-1 and an increase in areas with slight (5-15 $\mathrm{t} \mathrm{ha}^{-1}$ year $^{-1}$ ) and moderate (15-30 $\mathrm{t} \mathrm{ha}^{-1}$ year ${ }^{-1}$ ) soil loss, which represent $34 \%$ and $21 \%$ of the catchment area. The Pasture scenario also shows $13 \%$ of the catchment area with soil loss greater than $50 \mathrm{tha}^{-1}$ year $^{-1}$ (very severe), concentrated in the water divisor regions (Fig. 8B), while, under the Forest scenario, this soil loss is less than $5 \mathrm{tha}^{-1}$ year $^{-1}$ (Fig. 8E).

For the scenarios that consider only hilltop protected areas will retain vegetation coverage (3CF and 3RI), soil loss is close to that of the Pasture scenario; when compared to the Control scenario, forest decline results in intensified soil loss, especially in the watershed water divisors (Fig. 8D and Fig. 8G). Greater soil loss can intensify drainage system processes over time - an issue further compounded by increased surface runoff (Fig. 6A) in high-slope areas - and reduce useful storage volume in the Juturnaíba reservoir.

In the $2 \mathrm{CF}$ and $2 \mathrm{RI}$ scenarios, which are characterized by minimum vegetable coverage reduction or a small increase thereof when compared to the Control scenario, the spatial distribution of soil loss is close to that of the Control scenario (Fig. 8A, Fig. 8C and Fig. 8F). The differences between the scenarios that take into account Federal and State legislation (3CF and 3RI) are expressed in the number of hilltop protected area fragments when considering the Inea Resolution criteria, which considers the foot of the hill or the nearest body of water as the criteria for delimitation.

\subsection{Discussion}

Changes in hydrological responses caused by forest cover loss intensify sediment transport in the watershed. Restricting protected area status to hilltops alone does not meet the goal of the Forest Code and the Inea Resolution, which explicitly state that hilltop protected areas have the environmental role of safeguarding water resources and controlling soil erosion.

Maintaining only hilltops as protected areas does not prevent abrupt changes in the hydrological behavior of the São João river watershed. This is because protected areas in the watershed are not very sizeable if calculated according to new federal and state legislation (Magdalena et al., 2018). 
Besides the liquid discharge increases associated with the decline in evapotranspiration, LU/LC changes lead to significant shifts in streamflow patterns because of changes in flow paths. Atlantic Rainforest areas have smaller saturated zones, which leads to decreased surface runoff generation and larger retention of groundwater storage, resulting in better flow regulation in the dry season (Bonell, 2010; Khaledian et al., 2017; Salemi et al., 2013). Thus, the streamflow increases along the main channel in the reduced forest cover scenarios result in rapid responses to rainfall events and a decline in baseflow.

Surface runoff increases have a positive feedback effect on soil erosion processes over time (Bruijnzeel, 2004; Chen et al., 2007; Guo et al., 2019; Sthiannopkao et al., 2007). Associated with erosion processes energy sources (Fohrer et al., 2001; García Rodríguez and Giménez Suárez, 2010; Goss et al., 2014), these can also affect the drainage system and stability of the Juturnaíba reservoir, namely because of sediment deposition causing silting. This process can overload the reservoir with sediment and reduce the regularity of tributary streamflow rates (Chen et al., 2007; Sthiannopkao et al., 2007).

As such, preserving Atlantic Rainforest vegetation only in the areas delimited by legislation has a direct impact on the economic development of the watershed, a result of soil loss and the overload of sediments in the drainage system and the reservoir, subsequently affecting the water supply system. The results obtained with the Control scenario, wherein forested area remains larger than that required by law in association with agricultural uses in the plains, suggest that preserving a greater forested area in the watershed will lead to better regulated water flow in the channel and reduce soil loss, with consequent declines in silting and sediment deposition, thus facilitating better water resource retention for sustainable management in the watershed.

\section{Conclusions}

The results obtained in this manuscript indicate that restricting the coverage and dynamics of native vegetation only to hilltops does not prevent drastic changes in hydrological response in the watershed. Forest loss in the watershed may cause increases in surface runoff and a decline in baseflow, as well as soil loss. These changes can intensify sediment load in the São João river, causing its silting as well as sediment deposition in the reservoir used to protect water supply. Due to their small size, the hilltop protected areas created by the new legislation, proposed under the Forest Code and the Inea Resolution have failed to fulfill the environmental function of preserving the ecosystem services provided water resources and sediments deposition.

The hydrological modelling approach has been shown to constitute a good tool to estimate the potential impact public land use policies, such as the preservation of hilltop protected areas, can have on ecosystem services and the environmental function of landscapes.

\section{Declarations}

\section{Funding}

This work was developed with the support of CAPES, Brazil - Financing Code 001, CNPq Proceeding 308358/2018-0 and FAPERJ Proceeding E-26/211.062/2019 251191 and E-26/202.779/2019 247068, as well as São Paulo Research Foundation (FAPESP) Proceeding 2018/22907-1.

\section{Acknowledgements}

We thank the Programa de Pós-Graduação em Engenharia de Biossistemas da Universidade Federal Fluminense (UFF), the National Institute of Space Research (INPE), the Instituto Alberto Luiz Coimbra de Pós-Graduação e Pesquisa de Engenharia da Universidade Federal do Rio de Janeiro (COPPE/UFRJ) and the Universidade Estadual de Campinas for their support for the development of this work. Finally, we thank Prof. Dr. Thiago Sanna Freire Silva (University of Stirling) for his feedback and contributions to this manuscript.

\section{Availability of data and material}

Data are available from the corresponding author upon request.

\section{Code availability}

MHD-INPE hydrological model, ArcGIS ${ }^{8}$ 10.6, HAND model

Page 10/20 
All authors contributed to the study conception and design. URM: Writing - Original Draft, Methodology, Conceptualization, Formal analysis, Investigation; LGL: Software, DAR: Supervision, Writing - Review \& Editing, and Funding acquisition; CNF: Supervision, Writing - Review \& Editing. The first draft of the manuscript was written by URM and all authors commented on previous versions of the manuscript. All authors read and approved the final manuscript.

\section{Ethics Approval}

All work complies with ethical standards.

\section{Consent to Participate}

All authors give their permission.

\section{Consent for Publication}

All authors give their permission.

\section{Conflicts of Interest/Competing Interests}

The authors declare no competing interests.

\section{References}

1. Aghsaei, H., Mobarghaee Dinan, N., Moridi, A., Asadolahi, Z., Delavar, M., Fohrer, N., Wagner, P.D., 2020. Effects of dynamic land use/land cover change on water resources and sediment yield in the Anzali wetland catchment, Gilan, Iran. Sci. Total Environ. 712, 136449. https://doi.org/10.1016/j.scitotenv.2019.136449

2. Allen, R.G., Pereira, L.S., Raes, D., Smith, M., 1998. Crop evapotranspiration - Guidelines for computing crop water requirements FAO Irrigation and drainage paper 56 , Irrigation and Drainage. FAO, Rome, Italy.

3. Andrade, E.M., Guerreiro, M.J.S., Palácio, H.A.Q., Campos, D.A., 2020. Ecohydrology in a Brazilian tropical dry forest: thinned vegetation impact on hydrological functions and ecosystem services. J. Hydrol. Reg. Stud. 27, 100649. https://doi.org/10.1016/j.ejrh.2019.100649

4. Armenteras, D., Murcia, U., González, T.M., Barón, O.J., Arias, J.E., 2019. Scenarios of land use and land cover change for NW Amazonia: Impact on forest intactness. Glob. Ecol. Conserv. 17, e00567. https://doi.org/10.1016/j.gecco.2019.e00567

5. Ávila, L.F., 2011. Balanço hídrico em um remanescente de Mata Atlântica da Serra da Mantiqueira, MG. Universidade Federal de Lavras.

6. Badham, J., Elsawah, S., Guillaume, J.H.A., Hamilton, S.H., Hunt, R.J., Jakeman, A.J., Pierce, S.A., Snow, V.O., Babbar-Sebens, M., Fu, B., Gober, P., Hill, M.C., Iwanaga, T., Loucks, D.P., Merritt, W.S., Peckham, S.D., Richmond, A.K., Ames, D., Bammer, G., 2019. Effective modeling for Integrated Water Resource Management: A guide to contextual practices by phases and steps and future opportunities. Environ. Model. Softw. https://doi.org/10.1016/J.ENVSOFT.2019.02.013

7. Barral, M.P., Laterra, P., Maceira, N., 2019. Flood mitigation ecosystem service in landscapes of Argentina's Pampas: identifying winning and losing farmers. J. Environ. Manage. 240, 168-176. https://doi.org/10.1016/j.jenvman.2019.03.099

8. Bastos, J., Napoleão, P., 2011. 0 estado do ambiente: indicadores ambientais do Rio de Janeiro. Secretaria Estadual do Ambiente, Rio de Janeiro.

9. Benavidez, R., Jackson, B., Maxwell, D., Norton, K., 2018. A review of the (Revised) Universal Soil Loss Equation ((R)USLE): with a view to increasing its global applicability and improving soil loss estimates. Hydrol. Earth Syst. Sci. 22, 6059-6086. https://doi.org/10.5194/hess-22-6059-2018

10. Beskow, S., Mello, C.R., Norton, L.D., Curi, N., Viola, M.R., Avanzi, J.C., 2009. Soil erosion prediction in the Grande River Basin, Brazil using distributed modeling. Catena 79, 49-59. https://doi.org/10.1016/j.catena.2009.05.010

11. Beven, K.J., Kirkby, M.J., 1979. A physically based, variable contributing area model of basin hydrology. Hydrol. Sci. Bull. 24, 4369. https://doi.org/10.1080/02626667909491834 
12. Bonell, M., 2010. The impacts of global change in the humid tropics: Selected rainfall-runoff issues linked with tropical forestland management. Irrig. Drain. Syst. 24, 279-325. https://doi.org/10.1007/s10795-010-9104-8

13. Brasil, [Código Florestal (2012)], 2012. Lei $n^{\circ}$ 12.651, de 25 de maio de 2012. Dispõe sobre a proteção da vegetação nativa; altera as Leis $\mathrm{n}^{\circ} \mathrm{s}$ 6.938, de 31 de agosto de 1981, 9.393, de 19 de dezembro de 1996, e 11.428, de 22 de dezembro de 2006; revoga as Leis $n^{\circ} \mathrm{s} 4.771$, de 15 de setembro de 196. Brasil.

14. Brasil, [Constituição (1988)], 2016. Constitution of the Federative Republic of Brazil [recurso eletrônico]: constitutional text enacted on October 5, 1988, with the alterations established by Revision Constitutional Amendments No. 1, 1994 through 6 , 1994, by Constitutional Amendments No. 1, 5th ed, Brasília: Edições Câmara. Chamber of Deputies, Brasília.

15. Bruijnzeel, L.A., 2004. Hydrological functions of tropical forests: Not seeing the soil for the trees?, Agriculture, Ecosystems and Environment. https://doi.org/10.1016/j.agee.2004.01.015

16. Chen, L., Wei, W., Fu, B., Lü, Y., 2007. Soil and water conservation on the Loess Plateau in China: Review and perspective. Prog. Phys. Geogr. 31, 389-403. https://doi.org/10.1177/0309133307081290

17. Costa, T.C. e C. da, Lumbreras, J.F., Guimarães, S.P., Uzeda, M.C., 2005. Estimativas de perdas de solo para sub-bacias hidrográficas do estado do Rio de Janeiro. Bol. Pesqui. e Desenvolv. (Embrapa Solos).

18. Costanza, R., D’Arge, R., De Groot, R., Farber, S., Grasso, M., Hannon, B., Limburg, K., Naeem, S., O’Neill, R. V., Paruelo, J., Raskin, R.G., Sutton, P., Van Den Belt, M., 1997. The value of the world's ecosystem services and natural capital. Nature 387, $253-260$. https://doi.org/10.1038/387253a0

19. Costanza, R., de Groot, R., Braat, L., Kubiszewski, I., Fioramonti, L., Sutton, P., Farber, S., Grasso, M., 2017. Twenty years of ecosystem services: How far have we come and how far do we still need to go? Ecosyst. Serv. 28, 1-16.

https://doi.org/10.1016/j.ecoser.2017.09.008

20. Cunha, S.B., 1995. Impactos das obras de engenharia sobre o ambiente biofisico da bacia do rio São João (Rio de Janeiro Brasil). Universidade de Lisboa.

21. Cunha, S.B., 1991. Rectificação do rio São João efeitos na morfologia do canal e na ecologia. Rev. Port. Geogr. XXVI, 10.

22. Dantas, M.E., 2001. GEOMORFOLOGIA DO ESTADO DO RIO DE JANEIRO, in: ESTUDO GEOAMBIENTAL DO ESTADO DO RIO DE JANEIRO. CPRM - Serviço Geologico do Brasil, Brasilia.

23. DeFries, R., Hansen, A., Newton, A.C., Hansen, M.C., 2005. INCREASING ISOLATION OF PROTECTED AREAS IN TROPICAL FORESTS OVER THE PAST TWENTY YEARS. Ecol. Appl. 15, 19-26. https://doi.org/10.1890/03-5258

24. Desmet, P.J.J., Govers, G., 1996. A GIS procedure for automatically calculating the USLE LS factor on topographically complex landscape units. J. Soil Water Conserv. 5, 427-433.

25. Duan, Q., Sorooshian, S., Gupta, V., 1992. Effective and efficient global optimization for conceptual rainfall-runoff models. Water Resour. Res. https://doi.org/10.1029/91WR02985

26. Dunne, T., Black, R.D., 1970. Partial Area Contributions to Storm Runoff in a Small New England Watershed. Water Resour. Res. 6, 1296-1311. https://doi.org/10.1029/WR006i005p01296

27. Esri, 2019. ArcGIS Desktop: Release 10.6. Redlands.

28. Estoque, R.C., Ooba, M., Avitabile, V., Hijioka, Y., DasGupta, R., Togawa, T., Murayama, Y., 2019. The future of Southeast Asia's forests. Nat. Commun. 10, 1-12. https://doi.org/10.1038/s41467-019-09646-4

29. FAO, F. and A.O. of the U.N., 2016. Global Forest Resources Assessment 2015: How the worlds forests are changing?, 2nd ed, FAO Forestry. https://doi.org/10.1002/2014GB005021

30. Fohrer, N., Haverkamp, S., Eckhardt, K., Frede, H.-G., 2001. Hydrologic Response to land use changes on the catchment scale. Phys. Chem. Earth, Part B Hydrol. Ocean. Atmos. 26, 577-582. https://doi.org/10.1016/S1464-1909(01)00052-1

31. Frega, I., 2014. Resolução INEA 93/2014. DOUERJ 2012-2013.

32. Freitas, H.C. de, 2012. A Influência dos transportes advectivos na estimativa do balanço de CO2 do ecossistema: um estudo de caso para a mata atlântica com uso de técnicas micrometeorológicas. Esc. Super. Agric. Luiz Queiros. Universidade de São Paulo.

33. García Rodríguez, J.L., Giménez Suárez, M.C., 2010. Aplicación de algoritmos matemáticos en la determinación de la inclinación de pendiente en un entorno SIG. Aqua-LAC 2, 78-82.

Page 12/20 
34. Gash, J.H.C., Lloyd, C.R., Lachaud, G., 1995. Estimating sparse forest rainfall interception with an analytical model. J. Hydrol. 170, 79-86. https://doi.org/10.1016/0022-1694(95)02697-N

35. Goss, C.W., Goebel, P.C., Sullivan, S.M.P., 2014. Shifts in attributes along agriculture-forest transitions of two streams in central Ohio, USA. Agric. Ecosyst. Environ. 197, 106-117. https://doi.org/10.1016/j.agee.2014.07.026

36. Guo, Y., Peng, C., Zhu, Q., Wang, M., Wang, H., Peng, S., He, H., 2019. Modelling the impacts of climate and land use changes on soil water erosion: Model applications, limitations and future challenges. J. Environ. Manage. 250, 109403. https://doi.org/10.1016/j.jenvman.2019.109403

37. Gupta, H. V., Kling, H., Yilmaz, K.K., Martinez, G.F., 2009. Decomposition of the mean squared error and NSE performance criteria: Implications for improving hydrological modelling. J. Hydrol. 377, 80-91. https://doi.org/10.1016/j.jhydrol.2009.08.003

38. Hallema, D.W., Moussa, R., Sun, G., McNulty, S.G., 2016. Surface storm flow prediction on hillslopes based on topography and hydrologic connectivity. Ecol. Process. 5, 13. https://doi.org/10.1186/s13717-016-0057-1

39. Haregeweyn, N., Tsunekawa, A., Poesen, J., Tsubo, M., Meshesha, D.T., Fenta, A.A., Nyssen, J., Adgo, E., 2017. Comprehensive assessment of soil erosion risk for better land use planning in river basins: Case study of the Upper Blue Nile River. Sci. Total Environ. 574, 95-108. https://doi.org/10.1016/j.scitotenv.2016.09.019

40. Hutchinson, M.F., 1989. A new procedure for gridding elevation and stream line data with automatic removal of spurious pits. J. Hydrol. 106, 211-232. https://doi.org/10.1016/0022-1694(89)90073-5

41. Hutchinson, M.F., Stein, J.A., Stein, J.L., Xu, T., 2009. Locally adaptive gridding of noisy high resolution topographic data, in: Anderssen, R.S., Braddock, R.D., Newham, L.T.H. (Eds.), 18th World IMACS Congress and MODSIM09 International Congress on Modelling and Simulation: Interfacing Modelling and Simulation with Mathematical and Computational Sciences, Proceedings. Modelling and Simulation Society of Australia and New Zealand and International Association for Mathematics and Computers in Simulation, Cairns, Austrália, pp. 2493-2499.

42. Hutchinson, M.F., Xu, T., Stein, J.A., 2011. Recent Progress in the ANUDEM Elevation Gridding Procedure, in: Hengl, T., Evans, I. S., Wilson, J. P., Gould, M. (Eds.), Geomorphometry 2011. Redlands, CA, pp. 19-22.

43. Ikemoto, S.M., Napoleão, P.R.M., 2018. ATLAS DOS MANANCIAIS DE ABASTECIMENTO PÚBLICO DO ESTADO DO RIO DE JANEIRO Subsídios ao planejamento e ordenamento territorial, 1st ed. Instituto Estadual do Ambiente (RJ), Rio de JAneiro.

44. Jarvis, N.J., 1989. A simple empirical model of root water uptake. J. Hydrol. 107, 57-72. https://doi.org/10.1016/00221694(89)90050-4

45. Kelsen, H., 1967. Pure theory of law. Univ of California Press.

46. Khaledian, Y., Kiani, F., Ebrahimi, S., Brevik, E.C., Aitkenhead-Peterson, J., 2017. Assessment and Monitoring of Soil Degradation during Land Use Change Using Multivariate Analysis. L. Degrad. Dev. 28, 128-141. https://doi.org/10.1002/ldr.2541

47. Ley, R., Casper, M.C., Hellebrand, H., Merz, R., 2011. Catchment classification by runoff behaviour with self-organizing maps (SOM). Hydrol. Earth Syst. Sci. 15, 2947-2962. https://doi.org/10.5194/hess-15-2947-2011

48. Li, S., Yang, H., Lacayo, M., Liu, J., Lei, G., 2018. Impacts of land-use and land-cover changes on water yield: A case study in JingJin-Ji, China. Sustain. 10, 1-16. https://doi.org/10.3390/su10040960

49. Lombardi Neto, F., Moldenhauer, W.C., 1992. Erosividade da chuva: sua distribuição e relação com as perdas de solo em Campinas (SP). Bragantia 51, 189-196. https://doi.org/10.1590/S0006-87051992000200009

50. Loucks, D.P., Beek, E. van, Stedinger, J.R., Dijkman, J.P.M., Villars, M.T., 2005. Water resources systems planning and management: an introduction to methods, models and applications, UNESCO. ed. Paris, France.

51. Magdalena, U.R., Francisco, C.N., Rodriguez, D.A., 2018. Mapeamento das Áreas de Preservação Permanente (APP) no Topo de Morros de acordo com os Dispositivos Legais do Estado do Rio de Janeiro. Rev. Bras. Geogr. Física 11, 789-797. https://doi.org/10.26848/rbgf.v11.3.p789-797

52. Marchiori, N.M., Rocha, H.R. da, Tamashiro, J.Y., Aidar, M.P.M., 2016. TREE COMMUNITY COMPOSITION AND ABOVEGROUND BIOMASS IN A SECONDARY ATLANTIC FOREST, SERRA DO MAR STATE PARK, SÃO PAULO, BRAZIL. CERNE 22, 501-514. https://doi.org/10.1590/01047760201622042242

53. Mitchell, B., Stolton, S., Bezaury-Creel, J., Bingham, H., Cumming, T., Dudley, N., Fitzsimons, J., Malleret-King, D., Redford, K., Solano, P., 2018. Guidelines for privately protected areas. IUCN, International Union for Conservation of Nature. https://doi.org/10.2305/IUCN.CH.2018.PAG.29.en

Page $13 / 20$ 
54. Mohor, G.S., Rodriguez, D.A., Tomasella, J., Siqueira Júnior, J.L., 2015. Exploratory analyses for the assessment of climate change impacts on the energy production in an Amazon run-of-river hydropower plant. J. Hydrol. Reg. Stud. 4, 41-59. https://doi.org/10.1016/j.ejrh.2015.04.003

55. Moriasi, D.N., Arnold, J.G., Van Liew, M.W., Binger, R.L., Harmel, R.D., Veith, T.L., 2007. Model evaluation guidelines for systematic quantification of accuracy in watershed simulations. Trans. ASABE 50, 885-900. https://doi.org/10.13031/2013.23153

56. Niu, G.-Y., Yang, Z.-L., Mitchell, K.E., Chen, F., Ek, M.B., Barlage, M., Kumar, A., Manning, K., Niyogi, D., Rosero, E., Tewari, M., Xia, Y., 2011. The community Noah land surface model with multiparameterization options (Noah-MP): 1. Model description and evaluation with local-scale measurements. J. Geophys. Res. 116, D12109. https://doi.org/10.1029/2010JD015139

57. Nobre, A.D., Cuartas, L.A., Hodnett, M., Rennó, C.D., Rodrigues, G., Silveira, A., Waterloo, M., Saleska, S., 2011. Height Above the Nearest Drainage - a hydrologically relevant new terrain model. J. Hydrol. 404, 13-29. https://doi.org/10.1016/j.jhydrol.2011.03.051

58. Oliveira, G. de C., Filho, E.I.F., 2016. AUTOMATED MAPPING OF PERMANENT PRESERVATION AREAS ON HILLTOPS. Cerne 22, 111-120. https://doi.org/10.1590/01047760201622012100

59. Ovando, A., Tomasella, J., Rodriguez, D.A., Martinez, J.M., Siqueira-Junior, J.L., Pinto, G.L.N., Passy, P., Vauchel, P., Noriega, L., von Randow, C., 2016. Extreme flood events in the Bolivian Amazon wetlands. J. Hydrol. Reg. Stud. 5, 293-308. https://doi.org/10.1016/J.EJRH.2015.11.004

60. Pinto, L.C., Mello, C.R., Norton, L.D., Owens, P.R., Curi, N., 2016. Spatial prediction of soil-water transmissivity based on fuzzy logic in a Brazilian headwater watershed. CATENA 143, 26-34. https://doi.org/10.1016/j.catena.2016.03.033

61. Rennó, C.D., Nobre, A.D., Cuartas, L.A., Soares, J.V., Hodnett, M.G., Tomasella, J., Waterloo, M.J., 2008. HAND, a new terrain descriptor using SRTM-DEM: Mapping terra-firme rainforest environments in Amazonia. Remote Sens. Environ. 112, 3469-3481. https://doi.org/10.1016/j.rse.2008.03.018

62. Ribeiro, M.C., Metzger, J.P., Martensen, A.C., Ponzoni, F.J., Hirota, M.M., 2009. The Brazilian Atlantic Forest: How much is left, and how is the remaining forest distributed? Implications for conservation. Biol. Conserv. 142, 1141-1153. https://doi.org/10.1016/j.biocon.2009.02.021

63. Rochedo, P.R.R., Soares-Filho, B., Schaeffer, R., Viola, E., Szklo, A., Lucena, A.F.P., Koberle, A., Davis, J.L., Rajão, R., Rathmann, R., 2018. The threat of political bargaining to climate mitigation in Brazil. Nat. Clim. Chang. 8, 695-698.

https://doi.org/10.1038/s41558-018-0213-y

64. Rodriguez, D.A., Tomasella, J., 2015. On the ability of large-scale hydrological models to simulate land use and land cover change impacts in Amazonian basins. Hydrol. Sci. J. 6667, 150527103244004-150527103244004. https://doi.org/10.1080/02626667.2015.1051979

65. Salemi, L.F., Groppo, J.D., Trevisan, R., Moraes, J.M., Barros Ferraz, S.F., Villani, J.P., Duarte-Neto, P.J., Martinelli, L.A., 2013. Landuse change in the Atlantic rainforest region: Consequences for the hydrology of small catchments. J. Hydrol. 499, 100-109. https://doi.org/10.1016/j.jhydrol.2013.06.049

66. Schröter, M., Bonn, A., Klotz, S., 2019. Atlas of Ecosystem Services. Atlas Ecosyst. Serv. https://doi.org/10.1007/978-3-31996229-0

67. Shakya, N.M., Chander, S., 1998. Modelling of hillslope runoff processes. Environ. Geol. 35, 115-123. https://doi.org/10.1007/s002540050298

68. Silva, A.M., 2004. Rainfall erosivity map for Brazil. CATENA 57, 251-259. https://doi.org/10.1016/j.catena.2003.11.006

69. Soares-Filho, B., Rajão, R., 2018. Traditional conservation strategies still the best option. Nat. Sustain. 1, 608-610. https://doi.org/10.1038/s41893-018-0179-9

70. Soares-filho, B., Rajão, R., Macedo, M., Carneiro, A., Costa, W., Coe, M., Rodrigues, H., Alencar, A., 2014. Cracking Brazil 's Forest Code. Science (80-. ). 344, 363-364. https://doi.org/10.1126/science.124663

71. Spera, S.A., Galford, G.L., Coe, M.T., Macedo, M.N., Mustard, J.F., 2016. Land-use change affects water recycling in Brazil's last agricultural frontier. Glob. Chang. Biol. 22, 3405-3413. https://doi.org/10.1111/gcb.13298

72. Sthiannopkao, S., Takizawa, S., Homewong, J., Wirojanagud, W., 2007. Soil erosion and its impacts on water treatment in the northeastern provinces of Thailand. Environ. Int. 33, 706-711. https://doi.org/10.1016/j.envint.2006.12.007 
73. Tambosi, L.R., Vidal, M.M., Ferraz, S.F. de B., Metzger, J.P., 2015. Funções eco-hidrológicas das florestas nativas e o Código Florestal. Estud. Avançados 29, 151-162. https://doi.org/10.1590/S0103-40142015000200010

74. Tomasella, J., Hodnett, M., 2004. Pedotransfer functions for tropical soils, in: Developments in Soil Science. pp. 415-429. https://doi.org/10.1016/S0166-2481(04)30021-8

75. Tomasella, J., Sene Gonçalves, A., Schneider Falck, A., Oliveira Caram, R., Rodrigues Diniz, F.L.L., Rodriguez, D.A.A., Rodrigues do Prado, M.C.C., Negrão, A.C.C., Sueiro Medeiros, G., Chagas Siquiera, G., 2019. Probabilistic flood forecasting in the Doce Basin in Brazil: Effects of the basin scale and orientation and the spatial distribution of rainfall. J. Flood Risk Manag. 12, e12452. https://doi.org/10.1111/jfr3.12452

76. TUCCI, C., CLARKE, R., 1997. Impactos das mudanças da cobertura vegetal no escoamento: revisão. Rev. Bras. Recur. Hídricos 2 , 135-152. https://doi.org/10.21168/rbrh.v2n1.p135-152

77. Valeriano, M. de M., 2002. Programação do cálculo da declividade em SIG pelo método de vetores ortogonais. Rev. Espaço Geogr. 5, 69-85.

78. Vieira, R.R.S., Ribeiro, B.R., Resende, F.M., Brum, F.T., Machado, N., Sales, L.P., Macedo, L., Soares-Filho, B., Loyola, R., 2018. Compliance to Brazil's Forest Code will not protect biodiversity and ecosystem services. Divers. Distrib. 24, 434-438. https://doi.org/10.1111/ddi.12700

79. Wagner, F.H., Sanchez, A., Aidar, M.P.M., Rochelle, A.L.C., Tarabalka, Y., Fonseca, M.G., Phillips, O.L., Gloor, E., Aragão, L.E.O.C., 2020. Mapping Atlantic rainforest degradation and regeneration history with indicator species using convolutional network. PLoS One 15, e0229448. https://doi.org/10.1371/journal.pone.0229448

80. Williams, J.R., 1995. The EPIC model, in: Singh, V.. (Ed.), Computer Models of Watershed Hydrology. Water Resources Publications, Highlands Ranch, pp. 909-1000.

81. Wischmeier, W.H., Smith, D.D., 1958. Rainfall energy and its relationship to soil loss. Trans. Am. Geophys. Union 39, 285. https://doi.org/10.1029/TR039i002p00285

82. Xiang, H., Wang, Z., Mao, D., Zhang, J., Xi, Y., Du, B., Zhang, B., 2020. What did China's National Wetland Conservation Program Achieve区Observations of changes in land cover and ecosystem services in the Sanjiang Plain. J. Environ. Manage. 267, 110623. https://doi.org/10.1016/j.jenvman.2020.110623

83. Xue, Y., Zeng, F.J., Adam Schlosser, C., 1996. SSiB and its sensitivity to soil properties-a case study using HAPEX-Mobilhy data. Glob. Planet. Change 13, 183-194. https://doi.org/10.1016/0921-8181(95)00045-3

84. Zhao, R.J., Liu, X.R., 1995. The Xinanjiang model, in: Singh, V.P. (Ed.), Computer Models of Watershed Hydrology. Water Resources Publications, Colorado, USA, pp. 215-232.

\section{Figures}




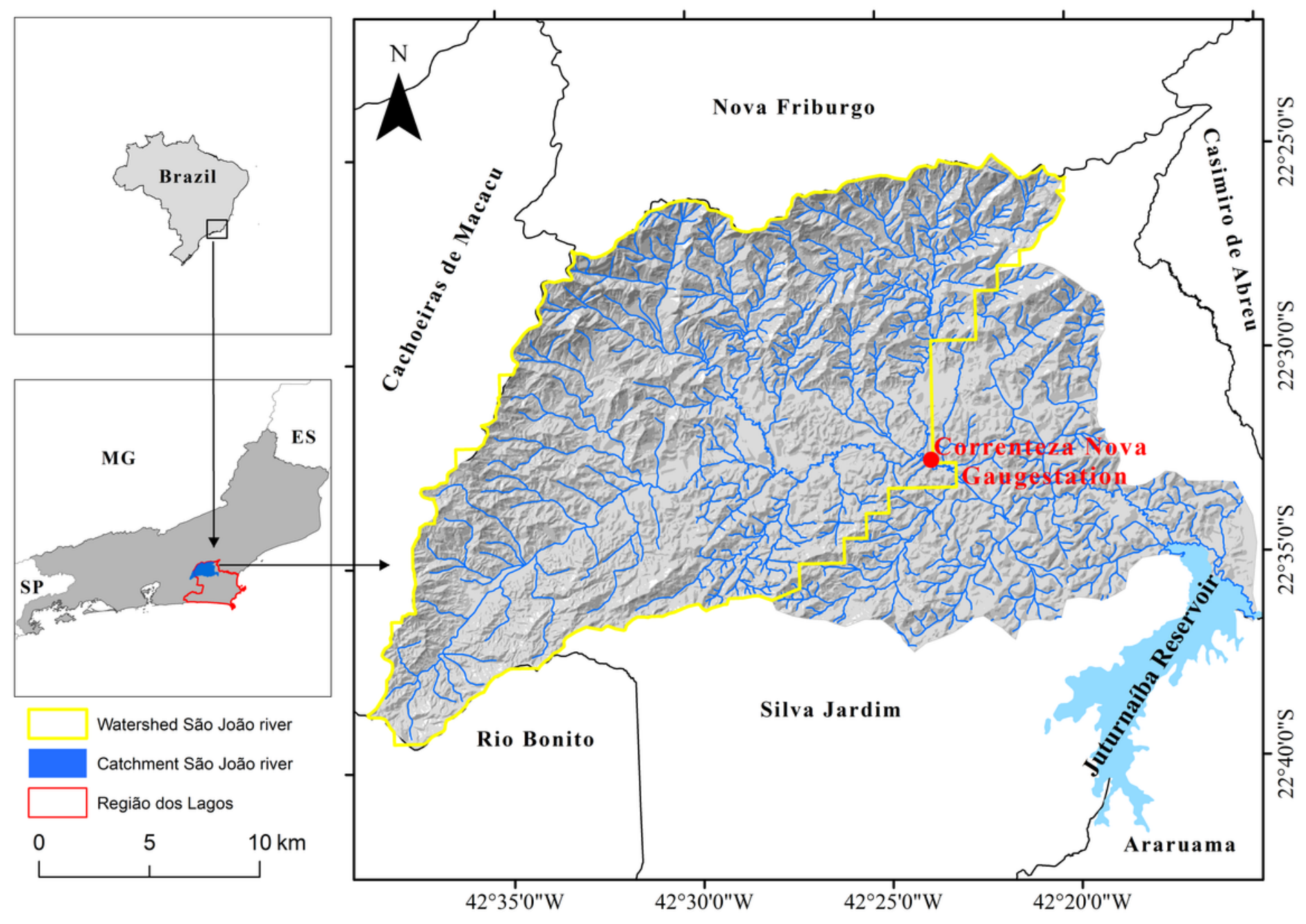

Figure 1

São João River watershed

政

Figure 2

LU/LC scenarios in the São João river watershed 

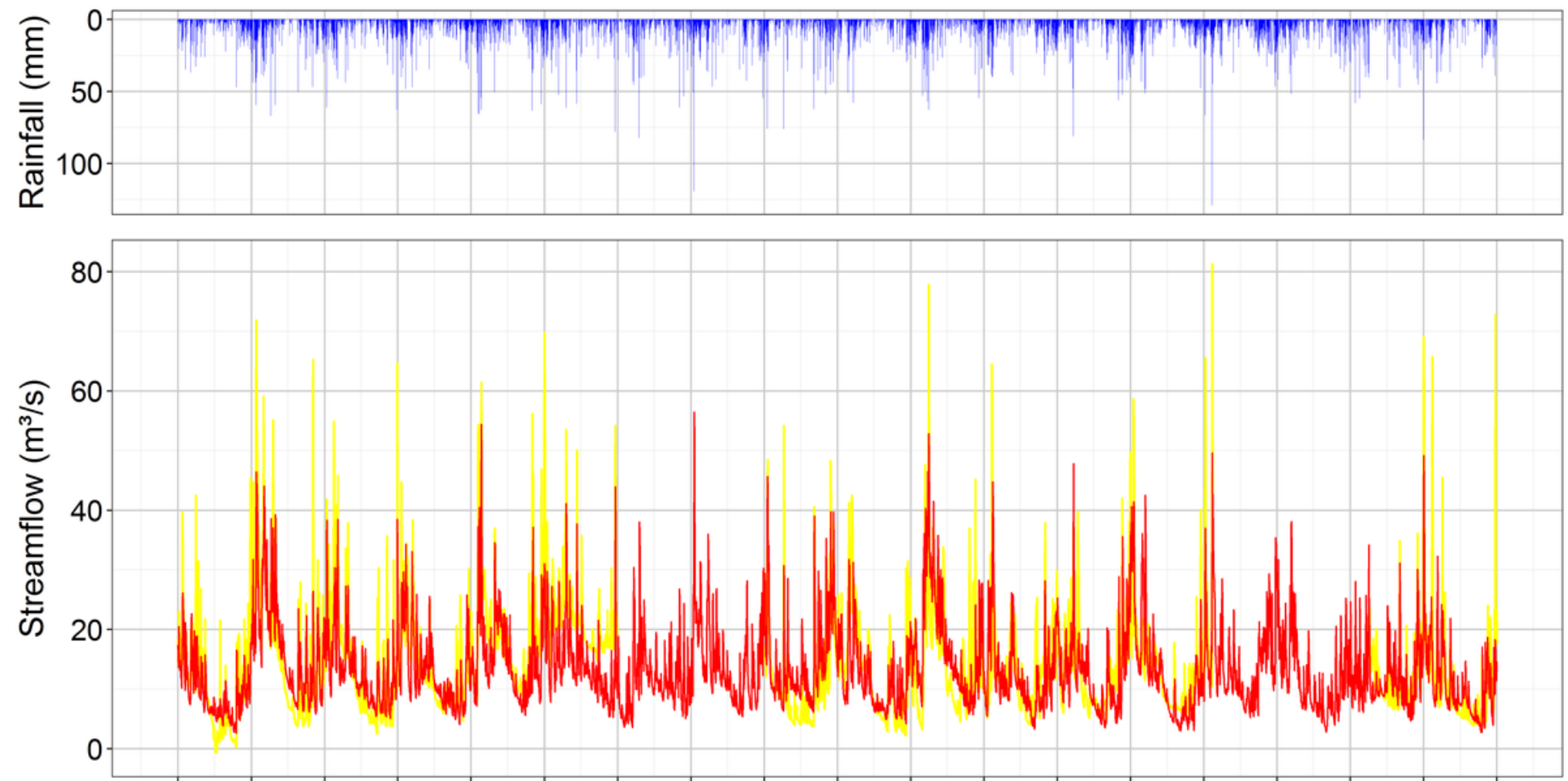

1984198519861987198819891990199119921993199419951996199719981999200020012002

$$
\text { Qobs - Qsimu }
$$

\section{Figure 3}

Comparison between observed streamflow (Qobs) at the Correntezas Nova gauge station and streamflow as simulated by the MHDINPE model (Qsimu), as well as rainfall distribution as simulated for the period from 1984 to 2002

A

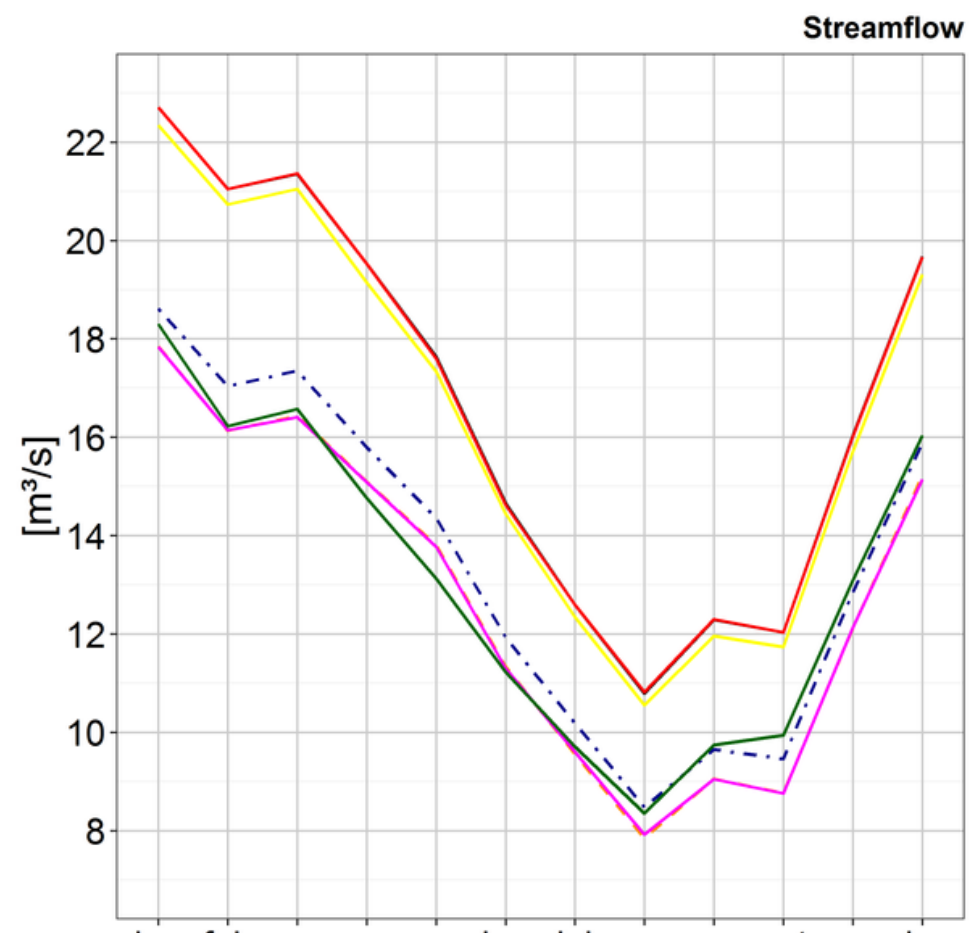

jan feb mar apr may jun jul aug sep oct nov dec
B

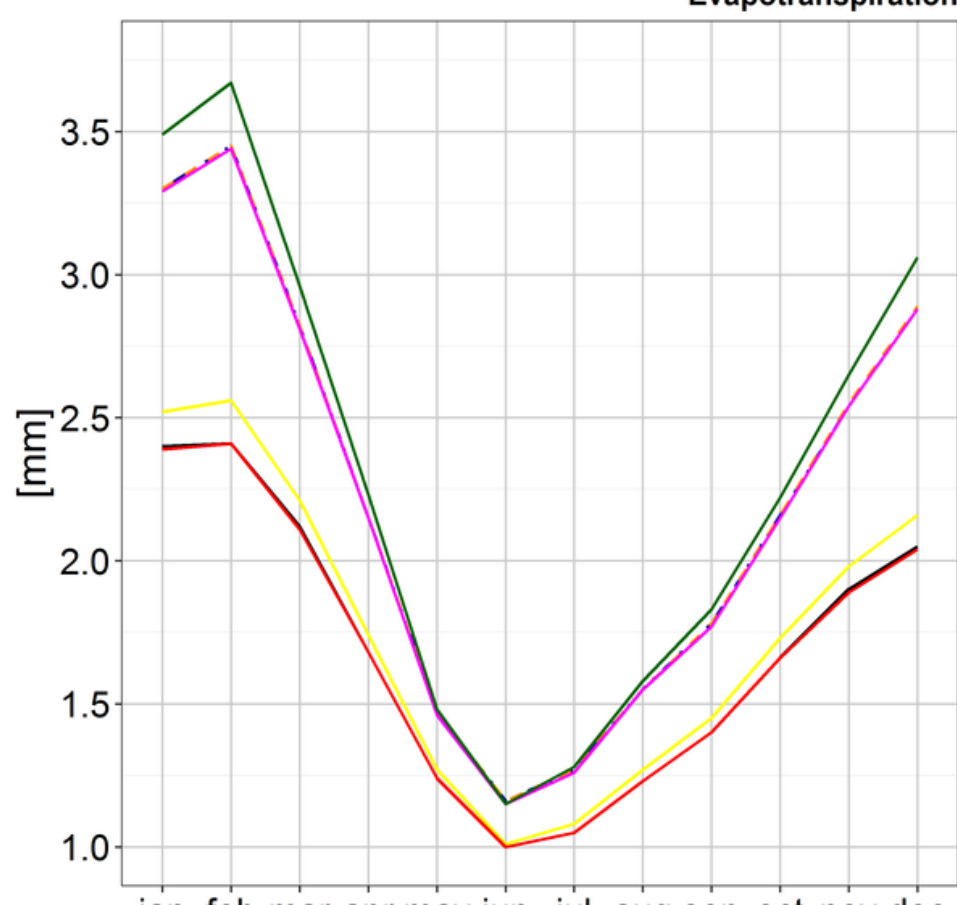

jan feb mar apr may jun jul aug sep oct nov dec

$$
\text { -.. Control - 2RI - 3RI - Forest }
$$


Figure 4

Long-term average seasonal variation of streamflow and evapotranspiration as simulated per the LU/LC scenarios in the São João river watershed

A

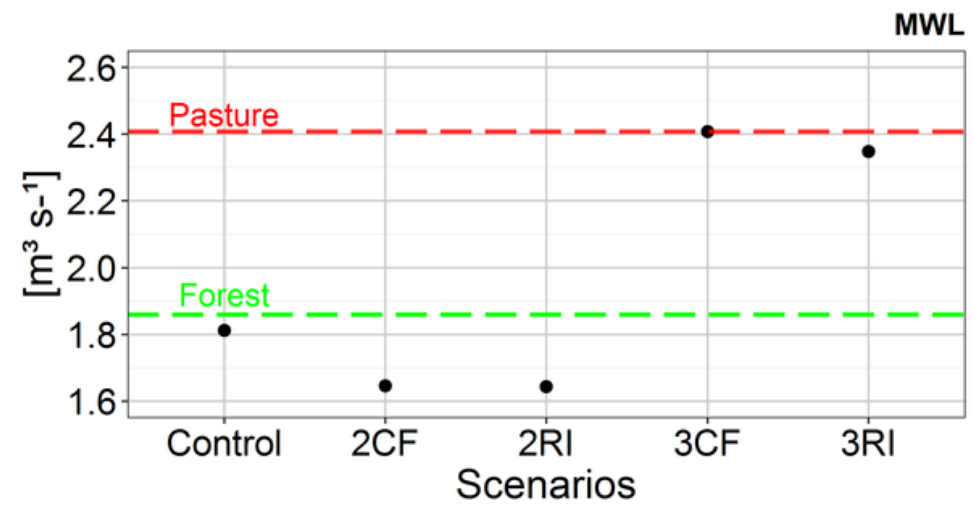

C

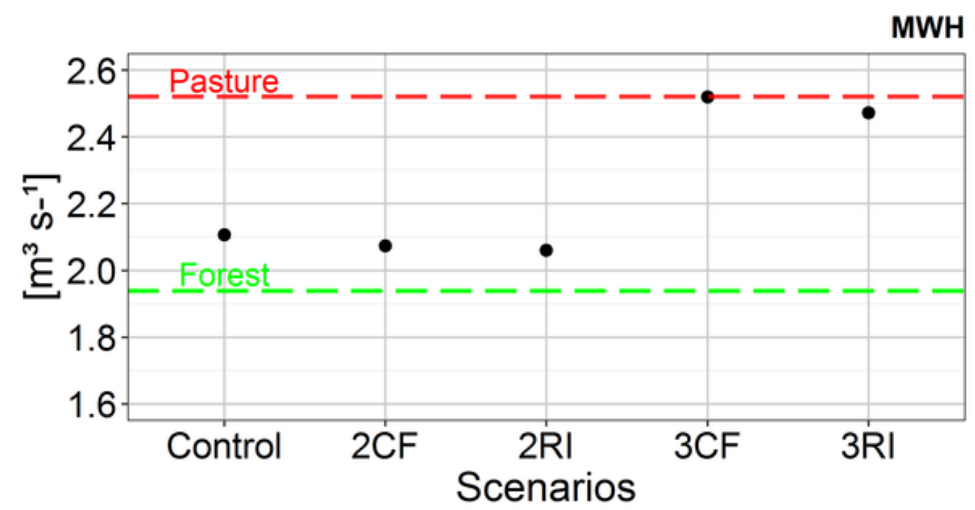

B

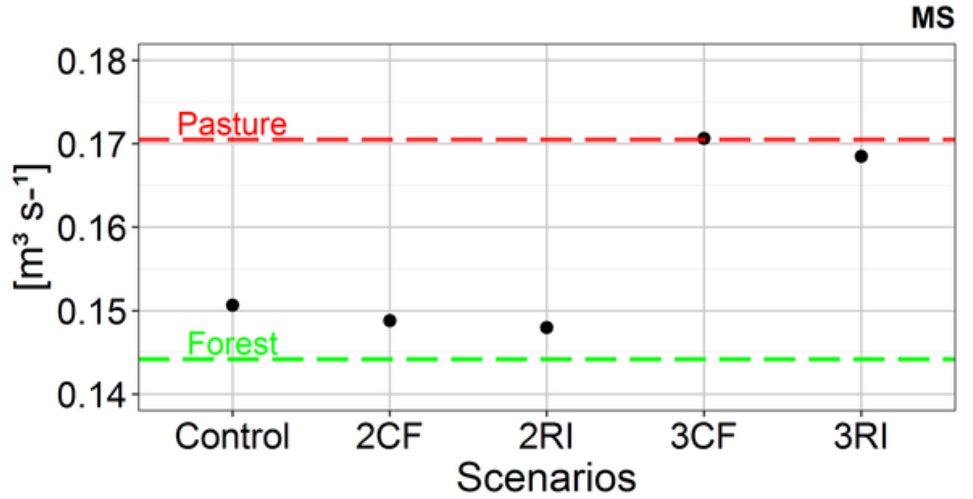

D

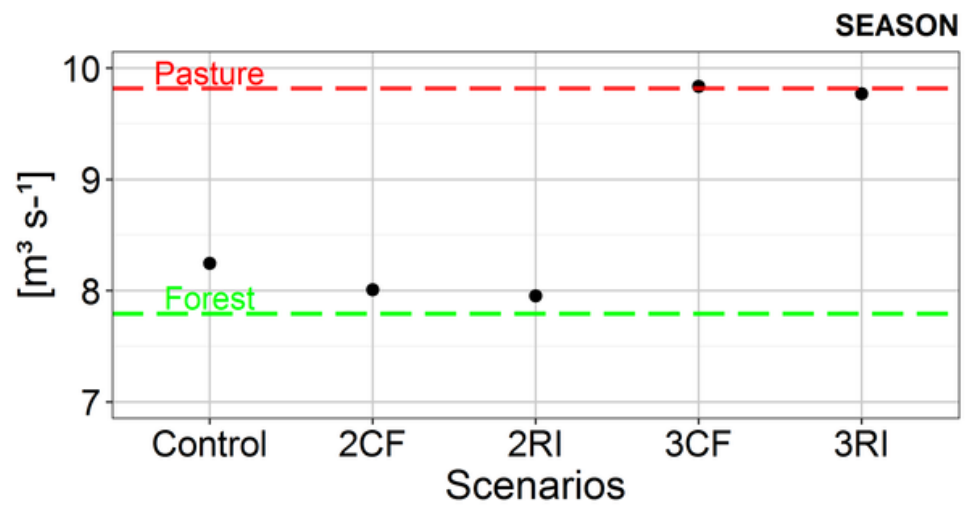

Figure 5

FDC variability for the watershed: mid-segment slope of the FDC - MS (A); low-flow segment volume of the FDC - MWL (B); highflow segment volume of the FDC - MWH (C); seasonality - SEASON (D) 
A

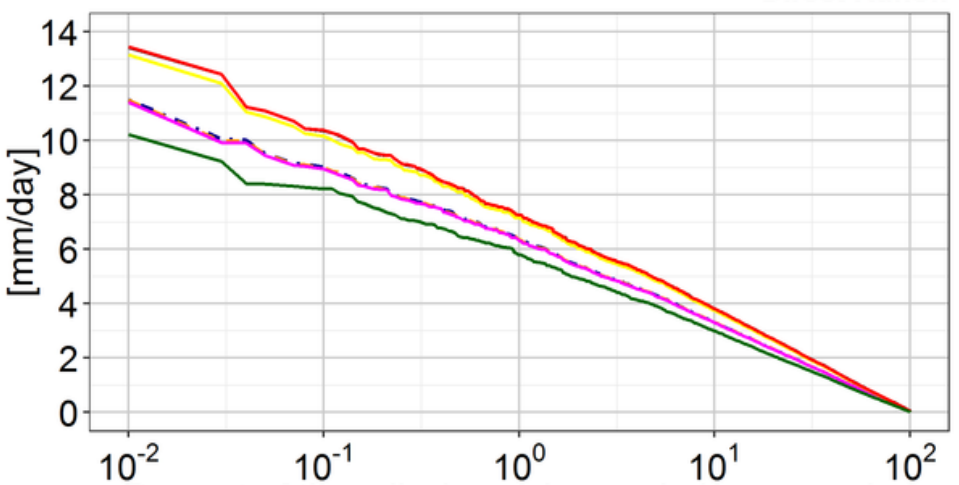

Percent of time discharge is equaled or exceeded

C

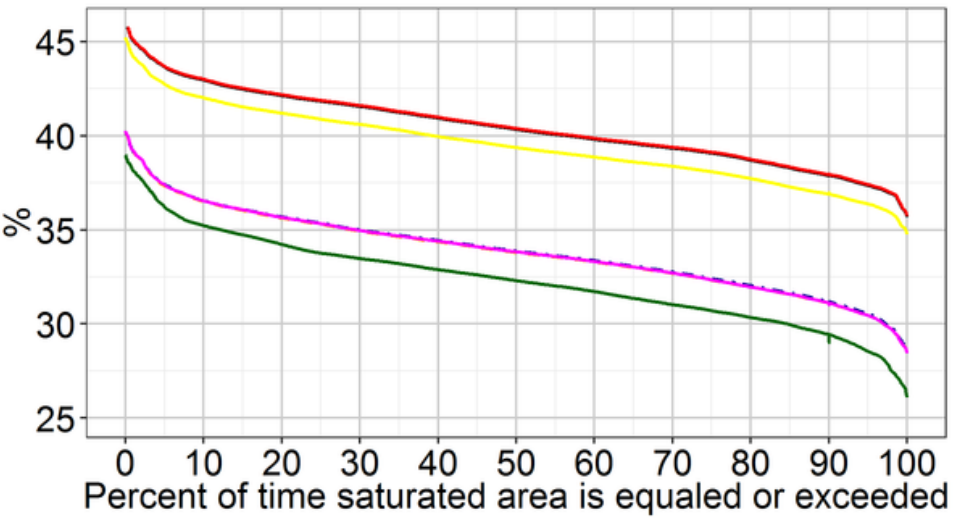

Base Runoff

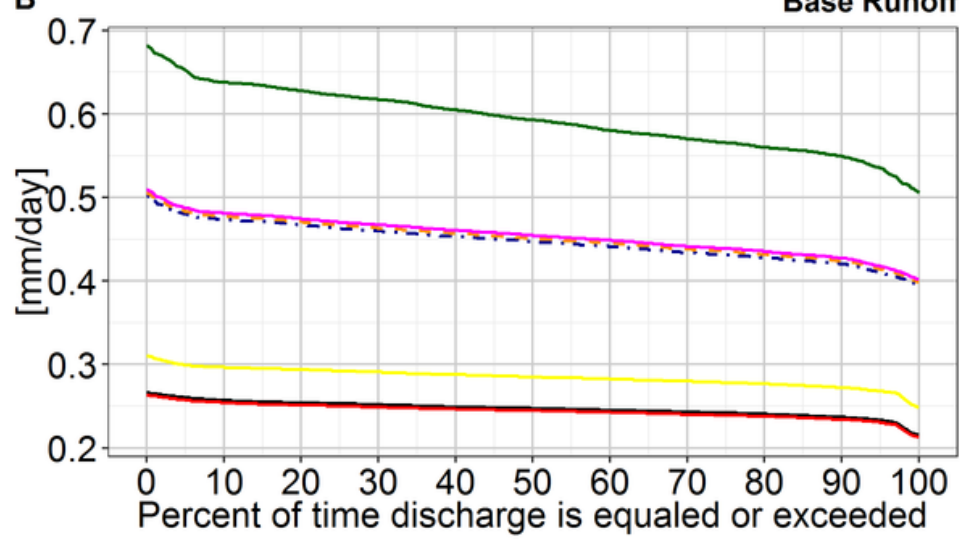

Figure 6

Hydrological responses of the catchment area: Saturated area $(A)$; direct runoff $(B)$ and base runoff $(C)$ 


\section{A}

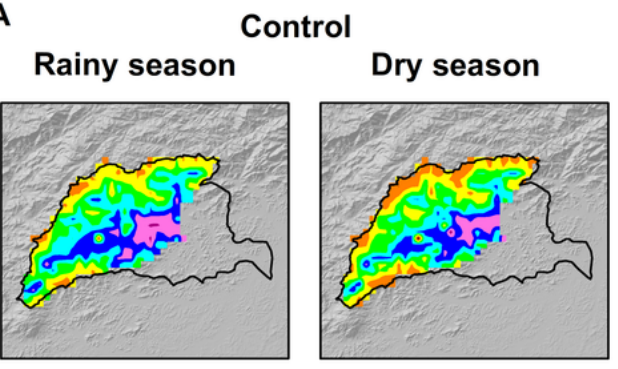

\section{Saturated Zones}
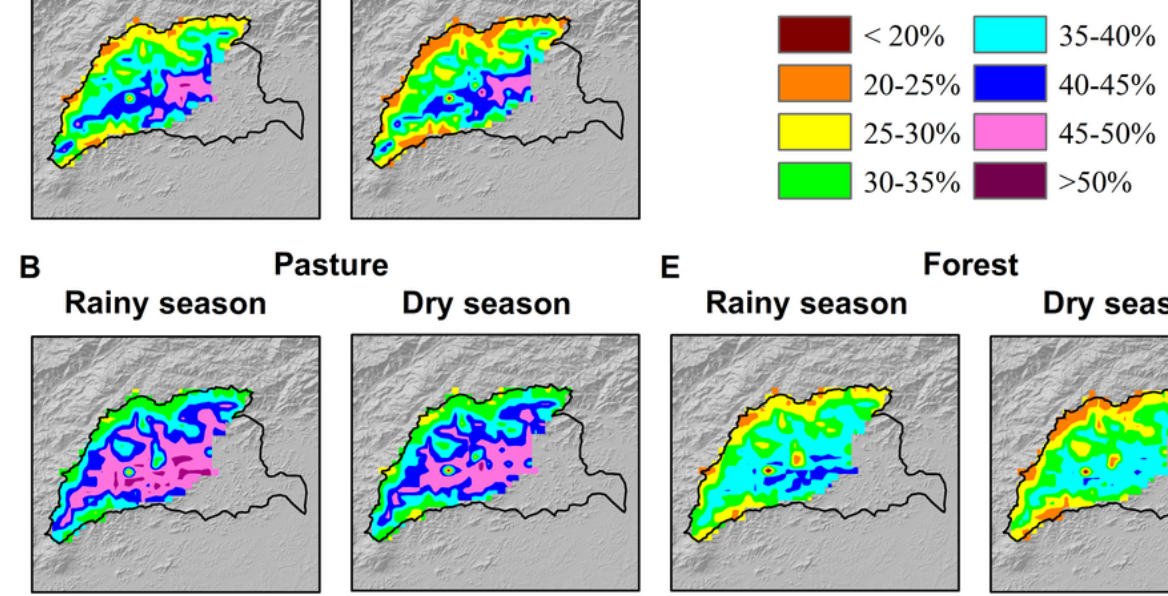

Pasture

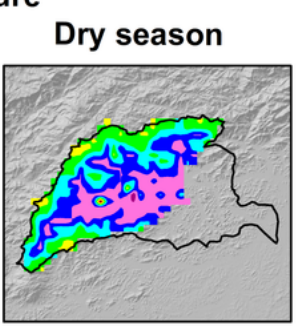

E Forest

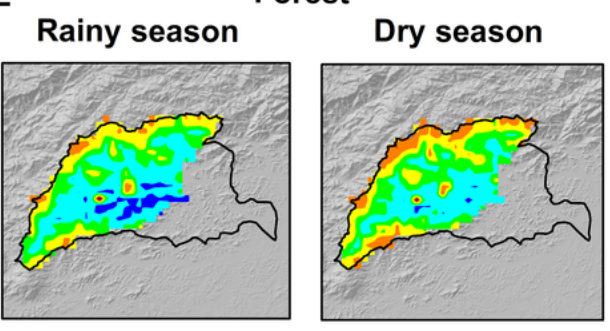

C

2CF

Rainy season

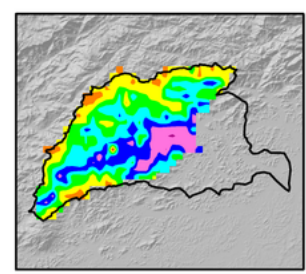

Dry season

F

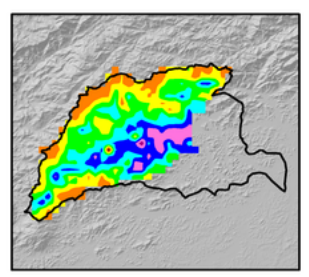

Rainy season

2RI

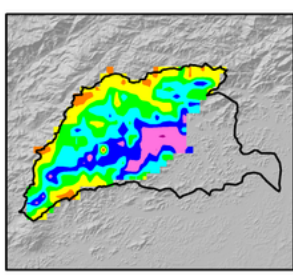

Dry season

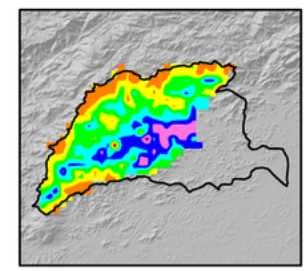

D

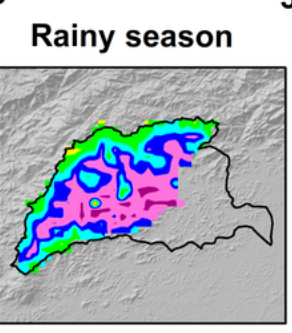

3CF

Dry season

G
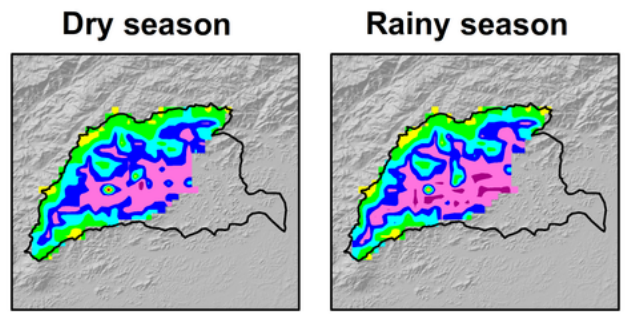

3RI

Dry season

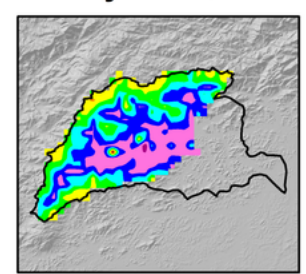

Figure 7

Spatial extent of saturated zones in the São João river catchment area

屈

Figure 8

Estimated average annual soil loss in the São João river watershed catchment area. The soil loss classes were adapted from Beskow et al. (2009) e Haregeweyn et al. (2017) 